\title{
ALGORYTMICZNOŚĆ BIOLOGII
}

\begin{abstract}
Streszczenie. Matematyczność fizyki jest zjawiskiem, którego obecność jest dla nas zaskakująca, ale które pozwala nam na poznanie przyrody poprzez analizę matematycznych struktur ją opisujących. Dotyczy to jednak wyłącznie fizyki. Stopień matematyzacji biologii jest niewielki, a próby użycia języka matematyki sprowadzają się w istocie do stosowania w biologii metod matematycznych, których używa się do opisu układów fizycznych. Jest prawdopodobne, że popełniamy w ten sposób błąd przypisując układom biologicznym cechy, których nie posiadają. Pojawiają się głosy, że biologia wymaga nowych metod matematycznych dostosowanych do jej potrzeb, nie znanych z fizyki. Sądzę jednak, że z uwagi na specyfikę złożoności, którą reprezentują układy biologiczne, zamiast o matematyczności biologii należy mówić o jej algorytmiczności. Jako przykłady algorytmicznego podejścia można przywołać tak zwane modele osobnicze używane między innymi do opisu dynamik populacji lub metody modelowania fraktalnego stosowane do opisu złożoności geometrii i jej dynamiki skomplikowanych struktur biologicznych, takich jak na przykład drzewa.
\end{abstract}

Słowa kluczowe: matematyczność fizyki, matematyczność biologii, algorytmiczność biologii

1. Wstęp. 2. Analityczność fizyki. 3. Zastosowania fizyki w biologii. 4. Biologia teoretyczna. 5. Korzyści, niebezpieczeństwa i wątpliwości. 6. Algorytmiczność biologii. 7. Koszty algorytmiczności i pewne jej zalety.

\section{WSTĘP}

Matematyka jest językiem nauk przyrodniczych. Zdanie to jest $\mathrm{z}$ całą pewnością prawdziwe w odniesieniu do fizyki. Wszystkie teorie fizyczne są sformułowane w języku matematycznym. Choć nie ma jedno-jednoznacznej relacji między treścią matematyki i fizyki a matematyka zawiera znacznie więcej treści niż potrzebuje fizyka, to jednak właśnie zapotrzebowaniu ze strony fizyki matematyka zawdzięcza w znacznym stopniu swoje osiągnięcia i swój oszałamiający rozwój. 
Jeśli „Pan Bóg myślał matematycznie tworząc świat”, to dlaczego miałby ograniczyć możliwość opisu matematycznego tylko do przyrody nieożywionej, zostawiając wyłącznie fizykom tę wspaniała możliwość odkrywania świata przy pomocy narzędzi matematycznych. Oceniając, na ile i jak matematyka jest używana w biologii, dochodzimy do bardzo pesymistycznych wniosków. Biologia jest zmatematyzowana w nieznacznym stopniu. Nie oddziałuje ona na matematykę. Trudno wskazać taki dział matematyki, który powstał na potrzeby biologii. Natomiast nie ulega najmniejszej wątpliwości, że biologia korzysta $z$ tych narzędzi matematycznych, które powstały na potrzeby fizyki. Mamy więc cały szereg pytań: dlaczego tak jest, że stopień matematyzacji biologii jest niewielki, czy poprawnie robimy używając w biologii metod właściwych fizyce i w końcu, co możemy zrobić w przyszłości, aby zrozumieć i rozwiązać te problemy.

Ktoś mógłby zauważyć, że przykładem metod matematycznych powstałych na potrzeby biologii może być statystyka matematyczna, której narzędzia są rzeczywiście wynikiem zapotrzebowania ze strony biologów czy też rolników. Otóż jest to zły przykład. Nie o takie zastosowania matematyki w tym miejscu chodzi. Statystyka służy wyłącznie do uporządkowania chaosu informacji wyłaniających się z eksperymentów. Fizyk zaś opisując językiem matematyki rzeczywistość fizyczną, a później, analizując właściwości powstałych w ten sposób matematycznych struktur, postępuje w sposób tak samo uprawniony jak jego kolega, który oddaje się empirycznym badaniom tych samych obiektów. Fizyk doświadczalny, przy pomocy technologii, którą się posługuje, sięga poza granice swych zmysłów. Teoretyk zaś, posługując się aparatem matematycznym, przekracza ograniczenia swojego umysłu albo nawyków i sposobów myślenia. Jeśli „księga przyrody pisana jest w języku matematycznym", to analiza struktur matematycznych opisujących tę przyrodę pozwala ją zrozumieć ${ }^{1}$. Tak, jak już wspominaliśmy,

1 M. Heller, Elementy mechaniki kwantowej dla filozofów, Copernicus Center Press, Warszawa 2014. 
z pewnością jest $\mathrm{w}$ fizyce. Tę cechę fizyki nazywamy jej matematycznością ${ }^{2}$. Taki też będzie punkt odniesienia, do którego będziemy się odwoływali zastanawiając się nad zagadnieniem zastosowania języka matematyki w biologii.

Zauważmy, że jedną z nieoczekiwanych korzyści z takiego, jak w fizyce, zastosowania matematyki jest to, że pozwala ono nam dostrzec w przyrodzie ład, porządek i symetrię, a to jest to, co daje nam poczucie zrozumienia świata i pozwala odczuć jego piękno ${ }^{3}$.

\section{ANALITYCZNOŚĆ FIZYKI}

Wszystkie obiekty, którymi zajmuje się biologia, to obiekty makroskopowe o stosunkowo dużych rozmiarach. Dlatego też zastanawiając się nad problemami matematyzacji biologii i porównując jej stan z matematycznością fizyki odwoływać się będziemy do klasycznych, makroskopowych działów fizyki, takich na przykład jak mechanika.

Sposób konstruowania matematycznego opisu świata fizycznego jest w zasadzie zawsze ten sam. Trzeba najpierw określić, co jest zmienną stanu właściwie opisującą właśnie ów stan badanego układu, a później przychodzi czas na podanie równań ujmujących zmiany stanu układu, czyli równań, które określą, co i w jaki sposób wpływa na dynamikę zmiennych stanu. W klasycznej mechanice, gdzie obiektami opisu są ciała materialne, zmiennymi stanu są położenie i prędkość każdego z nich, a równania dynamiki Newtona mówią nam, jak to położenia i prędkości będą się zmieniać, jeśli przyjmiemy dla nich pewne wartości początkowe.

Mając taki matematyczny opis obiektu, którym się zajmujemy, możemy poddać analizie jego strukturę matematyczną. Matematyczny

2 A. Lemańska, Matematyczność czy matematyzowalność przyrody?, Studia Philosophiae Christianae 49(2013)3, 5-24.

3 A. Lemańska, Rola matematyki w tworzeniu obrazu świata, w: Filozoficzne i naukowo-przyrodnicze elementy obrazu świata III, red. G. Bugajak, A. Latawiec, Warszawa 2001, 81-92. 
opis lub model rzeczywistości fizycznej pozwala nam nie tylko przewidywać przyszłe stany układu, co jest bardzo przydatne z praktycznego punktu widzenia, ale umożliwia także dostrzeżenie „rzeczy”, których istnienia bez przyjrzenia się strukturze matematycznej nie podejrzewalibyśmy. Kto bowiem mógłby przypuszczać, że analizy matematycznej struktury mechaniki klasycznej doprowadzi do sformułowania zasady ekstremum działania, czyli alternatywnego w stosunku do równań newtonowskich opisu dynamiki układów złożonego z ciał materialnych. Albo że do sformułowania równań dynamiki Newtona potrzebne jest pojęcie masy. Jakiż to obszar do zastanawiania się, co to takiego masa i dlaczego musi występować $\mathrm{w}$ równaniach dynamiki układu.

Nazwałbym taki sposób zastosowania matematyki w fizyce i taki sposób wykorzystania struktur matematycznych używanych w tym celu analitycznym. Jedną z cech tej analityczności jest całościowość matematycznego ujęcia teorii fizycznych. Nie mamy pojedynczych modeli, tylko spójną teorię opowiedzianą językiem matematycznym obejmującą na wysokim poziomie abstrakcji całość zagadnień. Struktura matematyczna podlega analizie metodami dostępnymi matematyce, przy czym wnioski z tej analizy, rozwiązania powiedzmy odpowiednich równań są osiągalne metodami analitycznymi bez uciekania się do metod numerycznych. Tych ostatnich czasami jesteśmy zmuszeni użyć, gdy stosujemy aparat matematyczny do bardzo konkretnego przypadku lub gdy analitycznego rozwiązania nie ma, ale cały czas pamiętamy, że każde takie szczególne zastosowanie ogólnej teorii opowiedzianej językiem matematyki, musi być zgodne z ogólnymi wnioskami analitycznymi, wynikającymi z właściwości wyjściowej struktury matematycznej teorii fizycznej. Niech za przykład posłuży tu fakt, znany z klasycznej mechaniki teoretycznej, nieistnienia analitycznego rozwiązania zagadnienia trzech ciał. To wynika z ogólnych właściwości struktury matematycznej, użytych w klasycznej mechanice. Jest to też stwierdzenie bardzo wysokiego rzędu. Obowiązuje wszędzie i zawsze tam, gdzie uzasadnione jest stosowanie klasycznej 
mechaniki. Ponieważ jednak układy trzech i więcej ciał materialnych nie są rzadkością w przyrodzie, to, pamiętając co mówi ogólna teoria, zawsze możemy uciec się do numerycznego ich rozwiązania.

\section{ZASTOSOWANIA FIZYKI W BIOLOGII}

Mniej więcej wiadomo, co jest żywe i wchodzi w zakres biologii, a co martwe i staje się obiektem zainteresowania fizyki. Ta granica jest dobrze określona. Natomiast bardzo płynna jest granica zastosowań $\mathrm{w}$ biologii matematycznych modeli zjawisk i procesów fizycznych. $\mathrm{W}$ bardzo wielu miejscach te opisy matematyczne znane $\mathrm{z}$ fizyki wkraczają na obszar biologii. Stosujemy je tam z wewnętrznym poczuciem, że mamy do tego prawo i że się nie mylimy, a matematyczny opis, który dostajemy, mimo że dotyczy obiektów biologicznych, jest poprawny.

Tradycyjnie w ożywionej części przyrody wyróżniamy poziomy organizacji. Wymieńmy tylko niektóre: poziom molekularny, komórkowy, przeskakując teraz kilka z nich wspomnijmy dalej o osobniku, populacji, ekosystemie i całej biosferze. Nie przypuszczam, aby było tak, jak chce tego część biologów, że poziomy te rządzą się swoimi prawami. Jestem raczej za tym, aby redukować właściwości wyższych poziomów do niższych posługując się rozsądnymi argumentami biologicznymi.

Tu użyję tego podziału tylko po to, aby pokazać mapę zastosowań fizyki w biologii. W wielu miejscach w biologii dostrzeżemy czysto fizyczne procesy. Przepływ krwi przez naczynia krwionośne. Dyfuzja substancji przez błony komórkowe. Rozprzestrzenianie się impulsów elektrycznych w sieciach neuronowych. Wszędzie tam zastosować można aparat matematyczny znany z fizyki i uzyskać poprawne rezultaty. Niektórzy zagadnienia tego typu zaliczają nie do obszaru biologii tylko fizyki i umieszczają w granicach tak zwanej biofizyki. Zwróćmy uwagę, że wszystkie te problemy należą do obszaru fizjologii. Tam rzeczywiście najczęściej w czystej postaci możemy 
stosować modele i metody matematyczne znane z fizyki. Oprócz tego jeśli chemię potraktujemy jako dziedzinę zastosowań fizyki, to obszarem, na który będziemy mogli rozszerzyć opis przy pomocy języka matematycznego używanego w fizyce, będą matematyczne modele reakcji biochemicznych. W tym momencie przenosimy się na poziom procesów komórkowych. To samo można powiedzieć o wielu zagadnieniach z dziedziny biologii molekularnej. Widać więc, że w bardzo wielu miejscach na niższych poziomach organizacji biologicznej możemy w sposób całkowicie uzasadniony stosować aparat matematyczny znany $z$ fizyki i podobnie jak w czystej fizyce oczekiwać poprawnych wyników, a być może i nowych rezultatów wynikających $z$ analizy użytych struktur matematycznych.

Jest jeszcze jeden obszar zastosowania fizyki, co prawda nie bezpośrednio związany z wejściem fizyki na teren biologii, ale taki, gdzie obie te nauki bardzo ściśle się stykają. Życie toczy się w środowisku. Choć często modyfikowane jest ono przez obecność żywych organizmów, to jednak przede wszystkim jest to środowisko fizyczne, do opisu którego możemy używać znanego nam aparatu matematycznego fizyki. Prądy oceaniczne, ruch wód w jeziorze, rozkład temperatury w zbiornikach wodnych, przemieszczanie się i temperatura mas powietrza to wszystko są zjawiska i procesy podlegające prawom hydrodynamiki. Dyfuzja tlenu i przepływ wody przez glebę to także procesy fizyczne, dla których znajdziemy w fizyce odpowiednie modele matematyczne. Wszystkie one wyznaczają ramy, w których życie musi znaleźć swoje miejsce, a znany z fizyki aparat matematyczny pozwala nam analizować wiele aspektów wpływu środowiska fizycznego na żywe organizmy.

Świadczy to, moim zdaniem, o tym, że biologia jest matematyzowalna, co oznacza ${ }^{4}$, że można w niej budować pojedyncze modele konkretnych zjawisk i procesów (niestety z przeważającym w nich udziałem fizyki), ale nie jest to dowód na matematyczność biologii

4 A. Lemańska, Matematyczność czy matematyzowalność przyrody?, art. cyt., 5-24. 
$\mathrm{w}$ takim znaczeniu tego terminu, $\mathrm{w}$ jakim stosuje się go do matematyczności fizyki.

\section{BIOLOGIA TEORETYCZNA}

W pewnych, jak sądzę przeważających, ale na pewno bardzo istotnych i bardzo „biologicznych”, obszarach biologii możliwości zastosowania fizyki wprost kończą się. Myślę, że obszar ten rozpoczyna się od poziomu osobnika włącznie i rozciąga się w górę poprzez populacje i wyżej do ekosystemu. Dlaczego osobnik stanowi tu punkt graniczny? Jest tak, ponieważ, wyrażając się trochę zbyt obrazowo, życie istnieje $\mathrm{w}$ formie osobników. Jeśli proces ewolucji na drodze doboru naturalnego uznamy za istotę procesów biologicznych, a żywym nazwiemy to, co jest produktem doboru naturalnego (oczywiście $\mathrm{w}$ biologicznym znaczeniu tego terminu), to osobnik jawi się nam jako produkt doboru naturalnego - najważniejszy, a może i jedyny. Jego cechy (łącznie $z$ jego zachowaniem), jego cele życiowe są produktem doboru naturalnego. Mają mu one zapewnić jak największy w konkretnych warunkach środowiska sukces reprodukcyjny. Obiekty fizyczne nie są produktem doboru naturalnego i w związku z tym nie podlegają ewolucji biologicznej. To właśnie różni newtonowskie punkty materialne od żywych osobników.

Punkty materialne mają swoją dynamikę opisaną równaniami mechaniki teoretycznej. Jaka mechanika jest właściwa żywym, biologicznym osobnikom. Odpowiedź jest bardzo prosta. Poczynając od poziomu osobników mamy w biologii pytanie, ile ich jest. Jest to pytanie o dynamikę populacji i zespołów populacji (czyli populacji różnych gatunków, których osobniki pozostają między sobą w różnych ekologicznych interakcjach). Jak dotychczasowa biologia teoretyczna radzi sobie z tym problemem? Mam na myśli oczywiście pytanie o to, jakich struktur matematycznych używa, aby uzyskać matematyczny opis dynamiki populacji i ich zespołów. 
Osiągnięcia fizyki są ogromne. Nie dziwi więc, że biologia teoretyczna postępuje dokładnie tak, jak się to robi w fizyce. Najpierw poszukuje się zmiennych stanu opisujących układ, a potem równań dających obraz dynamiki tych stanów. Jako zmiennych stanu używa się w biologii teoretycznej do matematycznego opisu dynamiki populacji i ich zespołów tak zwanych zagęszczeń populacji (jest to liczba osobników przypadająca w populacji na jednostkę powierzchni lub objętości środowiska). Natomiast równaniami dynamiki są tak zwane modele volterrowskie (od nazwiska Vito Volterry i jego książki, gdzie po raz pierwszy zostały opisane ${ }^{5}$. Żeby przybliżyć matematyczną strukturę tych modeli, przytoczę ich prostą wersję opisującą dynamikę dwóch oddziałujących między sobą różnogatunkowych populacji:

$$
\begin{gathered}
d N / d t=r_{n}\left(1-N / K_{n}\right) N-\alpha_{n} N M \\
d M / d t=r_{m}\left(1-N / K_{m}\right) N-\alpha_{m} N M
\end{gathered}
$$

$\operatorname{gdzie} N$ i $M$ to zagęszczenia populacji, a $r_{i}, K_{i}$ oraz $\alpha_{i}(i=1,2)$ są parametrami modelu. Pierwszy składnik stojący po prawej stronie kaźdego równania opisuje interakcje wewnątrz każdej z populacji osobno bez oddziaływań ze strony drugiej populacji. Zagęszczenia takich izolowanych populacji rosną asymptotycznie do pewnych ustalonych wartości (jest to w istocie zastosowanie najczęściej używanego w biologii równania logistycznego). Drugie człony po prawych stronach równań opisują interakcje między osobnikami obu populacji. Siła tych interakcji, jak widać, jest proporcjonalna do iloczynu zagęszczeń obu populacji, a różne kombinacje znaków przy współczynnikach je poprzedzających dają możliwość uwzględnienia różnych rodzajów interakcji międzygatunkowych. Wstawienie znaku „," osłabia tempo przyrostu populacji i oznaczać może drapieżnictwo, pasożytnictwo

5 V. Volterra, Lecons sur la theorie mathematique de la lutte pour la vie, Gauthier-Villars, paris 1931. 
lub konkurencję, a znaku „+" zwiększa je i symbolizuje na przykład mutualizm. Tu $-z$ uwagi na to, że przed współczynnikami $\alpha$ wstawiono minusy - zaprezentowano wersję modelu volterrowskiego opisującego konkurencje między gatunkami.

\section{KORZYŚCI, NIEBEZPIECZEŃSTWA I WĄTPLIWOŚCI}

Jakie korzyści mamy ze sformułowania modelu dynamiki populacji w takiej właśnie postaci? Przede wszystkim wspomnianą wcześniej analityczność zagadnienia. Analizując matematyczną strukturę tego modelu, badając jego własności oraz przeglądając to, co matematyka już wie na temat podobnych struktur, możemy nauczyć się wiele o funkcjonowaniu układów ekologicznych. Na przykład modele tego typu opisujące konkurencję między gatunkami dobrze oddają znaną od dawna ekologom z badań empirycznych zasadę konkurencyjnego wypierania gatunków, kiedy silniejszy konkurent doprowadza do wymarcia populacji słabszego. Niespodziewanym rezultatem, wynikłym wyłącznie z analizy matematycznej struktury tego typu modeli (choć bardziej złożonych niż wyżej przedstawiony) jest możliwość pojawienia się chaosu deterministycznego.

Czy świadczy to więc, że biologia jest nie tylko matematyzowalna, to znaczy, że można w niej stosować pewne modele matematyczne odtwarzające pewne jednostkowe procesy i zjawiska biologiczne, ale że ma ona tę szalenie istotną cechę, którą posiada fizyka, a mianowicie iż można mówić o jej matematyczności, co oznacza, że analizując samą matematyczną strukturę modeli dowiadujemy się o biologicznej rzeczywistości.

Aby odpowiedzieć na to pytanie, zastanówmy się, jakie niebezpieczeństwa kryją się za stosowaniem w biologii do opisu dynamiki populacji podejścia właściwego fizyce? Otóż - podobnie jak w fizyce - jeśliby struktura matematyczna użyta do tego celu okazała się niewłaściwa, to wszystkie wnioski zrobione na podstawie jej analizy byłyby także fałszywe. 
Szczyt wiary w ogromne możliwości volterrowskiego podejścia do opisu dynamiki układów ekologicznych przypadał na lata siedemdziesiąte, osiemdziesiąte i dziewięćdziesiąte ubiegłego wieku. Publikacje i książki Roberta Maya ${ }^{6}$ tchnęły przekonaniem, że oto dokonuje się wielka synteza, która doprowadziła do spójnej, zamkniętej teorii dynamiki układów ekologicznych zapisanej językiem matematyki. Słynne Mayowskie stwierdzenie, że złożoność układu ekologicznego oznacza jego stabilność, miało być najogólniejszym i najważniejszym wnioskiem wywiedzionym z tej teorii ${ }^{7}$. Później matematycy rosyjscy uzupełnili tę teorię o wiele szczegółów, jak również poprawili błędy Maya. Jednakże teoria ta w późniejszych latach w konfrontacji ze złożoną rzeczywistością ekologiczną jakby straciła swoją moc. Biolodzy przestali wierzyć w jej możliwości dlatego, że w oparciu o badania empiryczne bardzo trudno było orzekać o prawdziwości wniosków z niej wywiedzionych, a same one nie ujawniały rezultatów, które nieznane byłyby z wcześniejszych doświadczeń. Matematycy w dalszym ciągu stosowali (i stosują do dziś) to podejście, ale już nikt nie „trąbi” o totalnym sukcesie ${ }^{8}$. Sprawa przycichła. Obie strony milczą. I biolodzy, i matematycy nie dyskutują o sprawach zasadniczych, jednakże tam, gdzie zachodzi potrzeba użycia modelu dynamiki układu ekologicznego, choć bardzo często nie jest to najważniejszy element problemu, używa się modelu volterrowskiego.

W latach dziewięćdziesiątych zaczęły pojawiać się głosy krytykujące podejście volterrowskie. Zwracano uwagę, że osobniki to nie to samo co punkty materialne w mechanice teoretycznej i że szukanie

6 Na przykład Theoretical ecology. Principles and applications, red. R.M. May, W.B. Saunders Company, Philadelphia 1976.

7 R.M. May, Stability and complexity in model ecosystems, Princeton University Press, Princeton 1973.

8 Trzecie wydanie książki Maya po raz pierwszy wydanej w 1976 roku (Theoretical ecology. Principles and applications, red. R.M. May, A. McLean, Oxford University Press, Oxford 2007) uzupełniono zaledwie o parę haseł ekologicznych, ale nie widać w nim istotnego postępu merytorycznego, a przecież od pierwszego wydania upłynęło ponad trzydzieści lat. 
dla nich zmiennych stanu a później równań dla ich dynamiki nie jest właściwym podejściem'. Osobniki rodzą się, rosną, niektóre przechodzą kolejne stadia rozwojowe, rozmnażają się, wreszcie umierają. Punkty materialne lub inne ciała fizyczne obdarzone wyłącznie masą lub ładunkiem elektrycznym, są wieczne i mają niezmienne właściwości. Podkreślano, że osobniki charakteryzują się bardzo wyraźnie widoczną indywidualną zmiennością, szczególnie dostrzegalną u gatunków rozmnażających się płciowo, ale także u tych, których osobniki rosną długo i podlegają silnym interakcjom ekologicznym. Równocześnie z tą krytyką pojawiło się (częściowo nią wywołane, a częściowo będące tej krytyki przyczyną) tak zwane podejście osobnicze do modelowania dynamiki układów ekologicznych (IBMindividual-based modeling). Zgodnie z tym podejściem, przestajemy traktować układ ekologiczny jako układ dynamiczny z matematycznego punktu widzenia, którego stan możemy scharakteryzować pewną zmienną stanu, a zaczynamy opisywać losy osobników, ich wzrost oraz rozwój, interakcje między nimi prowadzące do indywidualnego zróżnicowania. Gdy stosujemy podejście osobnicze, dynamika liczebności układu ekologicznego staje się produktem ubocznym tego, co dzieje się z i między osobnikami. Budując takie modele, do rozwiązania tworzących je równań możemy posłużyć się wyłącznie symulacjami komputerowymi. Całkowicie więc tracimy elegancję analityczności modeli volterrowskich. Wyniki pojedynczej symulacji komputerowej są tyle warte, co wyniki pojedynczego eksperymentu, jaki może przeprowadzić biolog badający rzeczywistą przyrodę. Fizyk co prawda czasami pozwala sobie na symulacje komputerowe. Zawsze ma jednak do dyspozycji porządną teorię analityczną, a symulacja jest wyjściem wtedy, gdy analityczne rozwiązanie równań modelu

9 V. Grimm, J. Uchmański, Ecological systems are not dynamic systems: some consequences of individual variability, w: Predictability and nonlinear modeling in natural sciences and economics, red. J. Grasman, G. van Straten, Kluwer Academic Press, Dordrecht 1994, 248-259. 
jest zbyt trudne lub niemożliwe. Dla tych, którzy przywykli do analitycznych korzyści wynikających z zastosowania matematyki w fizyce, uciekanie się do symulacji komputerowych jako do jedynego opisu quasi-matematycznego bez posiadania za plecami dobrego, analitycznego modelu - tak jak zmuszeni są postępować ci, którzy stosują podejście osobnicze w ekologii - jest postępowaniem niemalże niegodnym.

\section{ALGORYTMICZNOŚĆ BIOLOGII}

Czy jest jakieś wyjście z zaistniałej sytuacji. Można oczywiście postulować - czasami takie głosy daje się słyszeć, sam byłem autorem takich propozycji ${ }^{10}-\dot{z}$ eby poczekać na pojawienie się nowej matematyki, dostosowanej do potrzeb i specyfiki biologii. Nie widać, niestety, nigdzie zapowiedzi świadczących o możliwości pojawienia się takiej odmiany „biologicznej” matematyki. Trudno nawet sobie wyobrazić, jaka miałaby to być matematyka. $Z$ rzadka słyszy się co prawda głosy, $\dot{z}$ e takie narzędzie już istnieje w postaci modeli uwzględniających wewnętrzną strukturę populacji (structured population models) lub modeli stochastycznych. Sądzę jednak, że te pierwsze są zwykłymi, klasycznymi, volterrowskimi modelami, nieznacznie tylko zmodyfikowanymi, które można obarczyć wszystkimi tymi zarzutami, co ich pierwotną wersję, a drugie także zawierają w sobie w istocie bardzo wiele volterrowskich założeń. Poza tym nie wszystkie procesy w biologii dają się opisać modelami stochastycznymi.

Przypuszczam, że rozwiązanie problemu polega na radykalnej zmianie naszych oczekiwań wobec możliwości zastosowania matematycznego opisu przyrody ożywionej i na uznaniu jej odmienności pod tym względem od przyrody nieożywionej. Sądzę bowiem, że biologia

10 J. Uchmański, Czy matematyka jest językiem ekologii?, Wiadomości Ekologiczne 26(1980), 221-231 lub późniejsza praca J. Uchmański, Matematyczność biologii, Filozofia i Nauka 3(2015), 345-352. 
ma naturę algorytmiczną, a nie analityczną. To jest zasadnicza, moim zdaniem, różnica między obiektami biologicznymi i fizycznymi, jeśli chodzi o możliwości zastosowania opisu matematycznego.

Algorytmem w ogólnym znaczeniu tego terminu nazywamy przepis, który określa po pierwsze obiekty, a po drugie czynności, które na tych obiektach zostaną wykonane ${ }^{11}$. Dla informatyka lub matematyka będzie to procedura obliczeniowa zwykle składająca się z wielu kroków obliczeniowych, która przekształca zbiór danych wejściowych w wyniki obliczeń ${ }^{12}$. Wyłącznie w taki algorytmiczny sposób, jak sądzę, można bez żadnych wątpliwości stosować język matematyki do opisu zjawisk i procesów ekologicznych, w których bezpośrednio uwzględniamy obecność osobników. Życie, jak już o tym mówiliśmy, istnieje w postaci osobników. Jest to najważniejsza przyczyna, dla której języka matematyki nie można stosować w biologii w taki sam sposób, jak robi się to w fizyce i która powoduje, że musimy tam używać podejścia algorytmicznego.

Jak już wspominałem wcześniej, wśród obiektów fizycznych nie działa dobór naturalny, mamy tam za to na przykład oddziaływania grawitacyjne pomiędzy punktami obdarzonymi masami. Wszystkie zaś obiekty prawdziwie biologiczne są produktem doboru naturalnego lub składają się z nich. Jednak dobór naturalny to nie to samo co grawitacja i nie mam tu na myśli faktycznej różnicy między tymi dwoma pojęciami, tylko różnicę w ich relacji do podstawowych składników układów fizycznych $z$ jednej strony, a biologicznych $z$ drugiej strony (relacja punkt materialny - siła grawitacji a relacja dobór naturalny - osobnik). Punkt materialny w klasycznej mechanice obdarzony jest stałą cechą (masą), a siła grawitacji określa interakcje między punktami materialnym. Dobór naturalny nie wyznacza

11 W.M. Turski, Propedeutyka informatyki, Państwowe Wydawnictwo Naukowe, Warszawa 1985.

12 T.H. Cormen, C.E. Leiserson, R.L. Rivest, Introduction to algorithms, Massachusetts Institute of Technolgy, Cambridge MA 1994. 
bezpośrednio interakcji między osobnikami. Dobór naturalny wyznacza cechy osobnika, a mówiąc dokładniej, czyni je takimi, aby osobnik osiągnął sukces reprodukcyjny w określonych warunkach, na które składa się także obecność innych osobników. Przy czym cechy osobnika są wynikiem działania doboru naturalnego na przodków osobnika, gdyż wśród osobników mamy przekazywanie informacji genetycznej między rodzicami a potomstwem (w istocie mamy także epigenetyczny i kulturowy przekaz informacji $\left.{ }^{13}\right)$. Dopiero potem tak ukształtowany osobnik zmuszony jest wejść w rzeczywiste interakcje ze środowiskiem i innymi osobnikami, aby osiągnąć swoje cele, a w istocie sam poddać się działaniu doboru naturalnego. Zachowanie punktu materialnego jest całkowicie zdeterminowane rozkładem mas pomiędzy punktami materialnymi i siłą grawitacji. Natomiast w biologii wyłącznie cechy osobnika są zdeterminowane przez dobór naturalny. Później w trakcie historii swojego życia osobnik ma bardzo dużo "swobody” w realizacji swoich celów życiowych. Nie do wszystkich okoliczności, jakie przyjdzie mu w życiu spotkać, dobór naturalny go dostosował. Nie wszystkie cele życiowe wszystkim osobnikom uda się zrealizować. Mało tego, ponieważ cechy osobnika nie powstają jednorazowo, tylko kształtują się przez sporą cześć jego życia w trakcie rozwoju organizmu, to mimo tego, że ich ramy są wyznaczone przez dobór naturalny, to jednak ich konkretna realizacja zależy od środowiska i interakcji ze strony innych osobników, z których każdy ma swoje własne cele (i są to cele często sprzeczne).

$\mathrm{Z}$ powyższych powodów, wykorzystując równania różniczkowe, można $\mathrm{w}$ fizyce zbudować teorię ruchu punktów materialnych, sformułować ją w języku matematyki i w pełni korzystać z jej analityczności. Analiza tej struktury matematycznej pozwala nam uzyskiwać informację o przyrodzie, ponieważ między tą ostatnią

13 E. Jablonka, M.J. Lamb, Evolution in four dimensions. Genetic, epigenetic, behavioral, and symbolic variation in the history of life, The Massachusetts Institute of Technology Press, Cambridge MA 2005. 
a jej matematycznym modelem istnieje pełna jedno-jednoznaczna odpowiedniość (dotyczy to również tych cech przyrody, których jeszcze nie znamy, a o istnieniu których dowiemy się dopiero analizując matematyczny model). A co możemy zrobić w przypadku przyrody ożywionej?

Przepiszmy układ (1) w postaci, które nie implikuje żadnego podejścia do matematycznego opisu tego biologicznego zagadnienia z zakresu dynamiki populacji. Uprościmy trochę jego budowę: będziemy rozważać tylko jedną populację. Zrezygnujemy także z ciągłości w czasie zagadnienia. Liczebność populacji będziemy rozważać w dyskretnych krokach czasowych: niech $N_{t}$ oznacza liczbę osobników w kroku czasowym $t$, a $\Delta N_{t}$ przyrost tej liczby w tym kroku czasowym. Wtedy:

$$
\Delta N_{t}=\Sigma z_{i}-\Sigma \delta_{i}
$$

gdzie $z_{i}$ jest liczbą potomstwa wyprodukowanego przez $i$-tego osobnika w kroku czasowym $t$, a $\delta_{i}$ jest funkcją o charakterze zbliżonym do delty Diraca: równa się ona jeden, gdy osobnik nie przeżył kroku czasowego $t$ i równa się 0 jeśli przeżył. Oba sumowania odbywają się po wszystkich osobnikach obecnych w populacji w kroku czasowym $t(i=1, \ldots, N)$.

I pierwsza, i druga suma stojąca po prawej stronie równania (2) jest wynikiem aktywności osobników. Tę aktywność można opisać quasi-matematycznie tylko w formie algorytmów: jeśli zachodzi warunek $A$, to osobnik „robi” $a$, jeśli $B$, to „robi” $b$ itd. Słowo „robi” należy tu rozumieć symbolicznie. To może być rzeczywiście jakieś zachowanie, ale może oznaczać wzrost i rozwój, rozmnażanie a także wiele procesów fizjologicznych, na przykład metabolizm. Także struktura tego algorytmu będzie bardziej złożona niż wyżej napisana. Takie algorytmy dla wszystkich osobników obecnych w kroku czasowym $t$ należałoby uruchomić współbieżnie, aby w regularnych odstępach czasu policzyć osobniki nowonarodzone i te, które 
umarły. Oczywiście algorytmy te nie tylko powinny być współbieżne, ale także wzajemnie sprzężone, aby uwzględnić interakcje między osobnikami (na przykład konkurencję). Zagadnienie jest trudne, ale możliwe do rozwiązania. Nie brakuje najrozmaitszych procedur numerycznych do rozwiązywania takich zagadnień. Wskazałbym tu bardzo liczne obecnie modele $\mathrm{z}$ kategorii modeli osobniczych budowane i używane w ekologii, o których bardzo skrótowo była wcześniej mowa ${ }^{14}$.

\section{KOSZTY ALGORYTMICZNOŚCI I PEWNE JEJ ZALETY}

Algorytmiczność pociąga za sobą nieubłaganie numeryczność. Jest to moim zdaniem największy koszt uświadomienia sobie algorytmiczności biologii. Tracimy wszystkie łatwo osiągalne właściwości przyrody, o których dowiedzieliśmy się dzięki analityczności modeli volterrowskich. Mogą się nawet te właściwości okazać fałszywe, gdyż nie wiemy, czy obraz przyrody zbudowany w oparciu o paradygmat algorytmiczny, będzie taki sam, jak zbudowany na klasycznej, volterrowskiej podstawie. A przecież tak łatwo było klasyfikować dynamikę układów ekologicznych na podstawie zachowań trajektorii układów równań różniczkowych w przestrzeniach fazowych. Przypuszczam, że przedefiniowania wymagać będzie tak ulubione przez ekologów i biomatematyków pojęcie stabilności. Moje doświadczenie z modelami osobniczymi pokazuje, że znacznie łatwiej uzyskać tam fluktuacje populacji, co dla modeli volerrowskich od zawsze było dynamiką trudną do osiągnięcia, jeśli zatroszczyliśmy się o poprawność założeń modelu ${ }^{15}$. Zauważmy, że dziedziną równania (2) są liczby naturalne. Konieczność przestrzegania tego ograniczenia jest pewnego rodzaju

14 V. Grimm, S. Railsback, Individual-based modeling and ecology, Princeton University Press, Princeton 2005.

15 J.P. Finerty, The population ecology of cycles in small mammals. Mathematical theory and biological facts, Yale University Press, New Haven 1980, ale patrz także R.M. Nisbet, W.S.C. Gurney, Modelling fluctuating populations, John Wiley \& Sons, Chichester 1982 
formalnym utrudnieniem, ale wyzwalamy się wtedy od mętnych interpretacji zmiennych w równaniach (1), które czasami są liczebnościami (liczby naturalne), a czasami zagęszczeniami populacji (liczby rzeczywiste). Rezygnując z modeli volterrowskich (które najczęściej są analizowane w ich różniczkowej postaci), uwalniamy się również od koszmaru ciągłości ich rozwiązań. Chyba nawet populacje bakterii nie spełniają tego warunku.

W istocie, biorąc za punkt wyjścia równanie (2) interpretowane w duchu algorytmiczności, można pokazaćc ${ }^{16}$, w jaki sposób krok po kroku, a właściwie założenie po założeniu dodawane do jego początkowej formy i początkowej interpretacji, możemy dojść do równań typu (1) interpretowanych w duchu analitycznym. Część tych założeń jest czysto formalna i poprawna (sprowadzają się one do uśredniania cech osobników w populacji lub w obrębie pokolenia), ale najważniejsze, te zmieniające jego interpretację, budzą moje ogromne wątpliwości. Zastępują bowiem one (wypowiedziane w duchu algorytmiczności) pytanie o to, który osobnik w danej chwili lub danych warunkach się rozmnoży, a który umrze (gdzie indywidualna zmienność osobników jest bardzo istotna), zależnością o charakterze statystycznym pomiędzy tempem przyrostu zagęszczenia populacji a tymże zagęszczeniem (gdzie indywidualna zmienność osobników znika zastąpiona wartościami średnimi). Modele volterrowskie roszczą sobie pretensje do wszechogarniającej ogólności. $Z$ powodu zawartego w nich założenia o uśrednianiu indywidualnej zmienności usiłuje się je stosować do opisu dynamiki liczebności wszystkich gatunków (na szczęście nie roślin lądowych). Dla mnie podstawową cechą przyrody żywej jest jej ogromna różnorodność, której w modelach volterrowskich nie można w wystarczającym stopniu uwzględnić

oraz J. Uchmański, Modele cyklicznych populacji, Wiadomości Ekologiczne 32(1986), 215-240.

16 J. Uchmański, Single population dynamics: differences between classical and individual-based modeling approaches, Russian Entomological Journal 21(2012), 197-201. 
poprzez zmiany parametrów tego modelu, a nie jego ogólnej postaci. Poza tym bardzo trudno jest wskazać choćby jeden gatunek, który bez wątpliwości spełniałby założenia modelu volterrowskiego.

Jak widać, moje przekonanie o algorytmiczności przyrody skłania mnie ku modelom osobniczym tam, gdzie chodzi o opis dynamiki liczebności. Jestem przeciwny stosowaniu modeli volterrowskich w tym przypadku. Uważam również za szkodliwe pojawiające się od czasu do czasu modele hybrydowe, które noszą cechy obu powyższych podejść do opisu dynamiki układów ekologicznych. Nie oznacza to, że nie widzą zastosowania równań różniczkowych i różnicowych w biologii, a szczególnie w ekologii. Te modele, które zajmuja opisem krążenia pierwiastków i przepływem energii w układach ekologicznych spokojnie mogą korzystać z tego aparatu matematycznego, w najgorszym razie jako bardzo dobrego przybliżenia, czego dowodem niech będą rozliczne bardzo użyteczne praktyczne zastosowania tych modeli.

Konieczność stosowania algorytmicznego podejścia dostrzec można nie tylko w przypadku matematycznego opisu dynamiki liczebności układów ekologicznych, ale także w innych dziedzinach biologii. Wiele lat temu Przemysław Prusinkiewicz i Aristid Lindenmayer opublikowali książkę pod bardzo znamiennym tytułem: Algorithmic beauty of plants ${ }^{17}$, w której zaprezentowali szereg modeli wzrostu i rozwoju geometrycznych struktur roślin. Najważniejszą ideą, do której autorzy starali się przekonać czytelników, było stwierdzenie, że rozwój roślin z uwzględnieniem geometrycznych złożoności ich nadziemnych i podziemnych części można efektywnie i poprawnie opisać tylko za pomocą odpowiednich fraktalnych algorytmów. Do tej pory, budując modele wzrostu roślin, posługiwano się równaniami różniczkowymi. Pozwalało to co najwyżej modelować wzrost masy rośliny, ale nie dawało narzędzi do odtwarzania sposobu

17 P. Prusinkiewicz, A. Lindenmayer, Algorithmic beauty of plants, Springer-Verlag, New York 1990. 
rozmieszczenia tej masy w dwu- lub trójwymiarowej przestrzeni. Nie mieliśmy więc narzędzi do budowy modeli rozwoju geometrycznej, wielowymiarowej struktury roślin. To ograniczenie rodziło wątpliwości, czy bez tych geometrycznych osobliwości rozwoju roślin jesteśmy w stanie prawidłowo modelować nawet sam wzrost masy drzewa. Modelowanie przy użyciu metod fraktalnych było później z powodzeniem stosowane do modelowania wzrostu i rozwoju szerokiej klasy innych organizmów modułowych, a więc oprócz roślin, także korali, gąbek i na przykład kolonii bakterii i grzybów ${ }^{18}$. Trzeba tu podkreślić, że podejście do opisu rozwoju roślin przy użyciu algorytmów fraktalnych nie ma odpowiednika w postaci modelu analitycznego. Nie jest to przybliżone, numeryczne rozwiązanie pewnego problemu opisywanego przy wykorzystaniu tradycyjnych metod modelowania zjawisk przyrodniczych. Jest to przykład wyłącznie algorytmicznego spojrzenia na modelowanie procesów biologicznych.

Sądzę, że najważniejszą przyczyną tego, że w biologii nie można stosować metod matematycznych znanych z fizyki, jest to, że układy biologiczne są o wiele bardziej złożone od układów fizycznych, a natura tej złożoności jest także zupełnie inna. Jedynym jak dotąd dostępnym narzędziem matematycznym do oceny tej złożoności i modelowania jej dynamiki są właśnie metody fraktalne ${ }^{19}$. Jednakże, jak już wspomniałem, stosowanie ich sprowadza się prawie wyłącznie do budowy i symulacji komputerowej pewnych algorytmów.

Wykorzystanie algorytmów do rozwiązywania problemów, których nie da się w inny sposób ,ugryźć”, nie jest niczym nowym w matematyce. Istnieje bowiem pojęcie eksperymentu matematycznego ${ }^{20}$, którego dotychczasowe wykorzystanie jest $\mathrm{w}$ istocie co do zasady

18 J. Kaandorp, Fractal modelling. Growth and form in biology, Springer-Verlag, Berlin 1994.

19 A. Gazda, Geometria fraktalna i niektóre jej zastosowania w ekologii, Wiadomości Ekologiczne 42 (1996), 163-178.

20 A. Lemańska, Czy matematyka staje się nauką eksperymentalną?, Zagadnienia Naukoznawstwa 30(1994), 45-51 oraz A. Lemańska, Zagadnienia eksperymentu w matematyce w świetle teorii fraktali i chaosu deterministycznego, w: Byt, logos, matematyka. Filozofia/ 
bardzo bliskie do tego, co w odniesieniu do biologii proponowane jest w tej pracy. Ekologia wydaje się dostarczać bardzo wielu przykładów procesów i zjawisk, których ukrytą naturę można poznać, posługując się właśnie metodą eksperymentu matematycznego przeprowadzanego przy wykorzystaniu symulacji komputerowych odpowiednich algorytmów.

Czego można w przyszłości oczekiwać od podejścia algorytmicznego w biologii? Modele osobnicze w ekologii - drugi oprócz modelowania fraktalnego obszar zastosowania podejścia algorytmicznego w biologii - stanowią obecnie miriadę najrozmaitszych modeli budowanych na potrzeby chwili. Na pewno wymagają one znacznie większego stopnia standaryzacji (standardowe modele do standardowych sytuacji ekologicznych) i odpowiednich metod ich uogólniania. Pierwszy krok w tym kierunku został już zrobiony. Proponuje się mianowicie tak zwany protokół ODD, wprowadzający standardowy sposób opisu celu, właściwości i sposobu użycia modelu osobniczego ${ }^{21}$. $Z$ drugie strony trudno przewidzieć wszystkie aspekty przyszłego rozwoju tego nowego spojrzenia na zastosowanie metod matematycznych do opisu przyrody ożywionej.

\section{BIBLIOGRAFIA}

Cormen T.H., Leiserson C.E., Rivest R.L., Introduction to algorithms, Massachusetts Institute of Technolgy, Cambridge MA 1994.

Finerty J.P., The population ecology of cycles in small mammals. Mathematical theory and biological facts, Yale University Press, New Haven 1980.

Gazda A., Geometria fraktalna i niektóre jej zastosowania w ekologii, Wiadomości Ekologiczne 42(1996), 163-178.

Grimm V., Uchmański J., Ecological systems are not dynamic systems: some consequences of individual variability, w: Predictability and nonlinear modeling in natural

logika, filozofia logiczna, red. J. Perzanowski, A. Pietruszczak, Wydawnictwa UMK, Toruń 1997, 401-408.

21 S. Reilsback, V. Grimm, Agent-based and individual-based modeling. A practical introduction, Princeton University Press, Princeton 2012. 
sciences and economics, red. J. Grasman, G. van Straten, Kluwer Academic Press, Dordrecht 1994, 248-259.

Grimm V., Railsback S., Individual-based modeling and ecology, Princeton University Press, Princeton 2005.

Heller M., Elementy mechaniki kwantowej dla filozofów, Copernicus Center Press, Warszawa 2014.

Jablonka E., Lamb M. J., Evolution in four dimensions. Genetic, epigenetic, behavioral, and symbolic variation in the history of life, The Massachusetts Institute of Technology Press, Cambridge MA 2005.

Kaandorp J., Fractal modelling. Growth and form in biology, Springer-Verlag, Berlin 1994.

Lemańska A., Czy matematyka staje się naukq eksperymentalna??, Zagadnienia Naukoznawstwa 30(1994), 45-51.

Lemańska A., Zagadnienia eksperymentu w matematyce w świetle teorii fraktali i chaosu deterministycznego, w: Byt, logos, matematyka. Filozofia/logika, flozofia logiczna, red. J. Perzanowski, A. Pietruszczak, Wydawnictwa UMK, Toruń 1997, 401-408.

Lemańska A., Rola matematyki w tworzeniu obrazu świata, w: Filozoficzne i naukowo-przyrodnicze elementy obrazu świata III, red. G. Bugajak, A. Latawiec, Warszawa 2001, 81-92.

Lemańska A., Matematyczność czy matematyzowalnośćprzyrody?, Studia Philosophiae Christianae 49(2013)3, 5-24.

May R.M., Stability and complexity in model ecosystems, Princeton University Press, Princeton 1973.

May R.M. (red.), Theoretical ecology. Principles and applications, W. B. Saunders Company, Philadelphia 1976.

Theoretical ecology. Principles and applications, red. May R.M., McLean A., Oxford University Press, Oxford 2007.

Nisbet R. M., Gurney W. S. C., Modelling fuctuating populations, John Wiley \& Sons, Chichester 1982.

Prusinkiewicz P., Lindenmayer A., Algorithmic beauty of plants, Springer-Verlag, New York 1990.

Reilsback S., Grimm V., Agent-based and individual-based modeling. A practical introduction, Princeton University Press, Princeton 2012.

Turski W. M., Propedeutyka informatyki, Państwowe Wydawnictwo Naukowe, Warszawa 1985.

Uchmański J., Czy matematyka jest językiem ekologii?, Wiadomości Ekologiczne 26(1980), 221-231. 
Uchmański J., Single population dynamics: differences between classical and individual-based modeling approaches, Russian Entomological Journal 21(2012), 197-201. Uchmański J., Matematyczność biologii, Filozofia i Nauka 3(2015), 345-352. Uchmański J., Modele cyklicznych populacji, Wiadomości Ekologiczne 32(1986), 215-240.

Volterra V., Lecons sur la theorie mathematique de la lutte pour la vie, Gauthier-Villars, Paris 1931.

\section{ALGORITHMICITY OF BIOLOGY}

Abstract. Mathematicity of physics is surprising, but it enables us to understand the laws of nature through the analysis of mathematical structures describing it. This concerns, however, only physics. The degree of the mathematization of biology is low, and attempts to mathematize it are limited to the application of mathematical methods used for the description of physical systems. When doing so, we are likely to commit an error of attributing to ecological systems features that they do not have. Some argue that biology does need new mathematical methods conforming to its needs, and not known from physics. In my opinion, however, because of a specific complexity of biological systems, we should speak of algorithmicity of biology, rather than of its mathematicity. As an example of algorithmic approach in biology one can indicate so called individual-based models used to describe population dynamics or fractal models applied to describe geometrical complexity of biological structures.

Keywords: mathematicity of physics, mathematicity of biology, algorithmicity of biology

\footnotetext{
JANUSZ UCHMAŃSKI

j.uchmanski@uksw.edu.pl

Uniwersytet Kardynała Stefana Wyszyńskiego w Warszawie, Instytut Ekologii i Bioetyki

Wóycickiego 1/3, 01-938 Warszawa

DOI 10.21697/spch.2016.52.1.05
} 